\title{
Biologi Rajungan Ditinjau dari Aspek Morfometrik dan Sex Ratio yang Didaratkan di Perairan Rembang
}

\author{
Muhammad Juli Hendra Putra*, Subagiyo, Ria Azizah Tri Nuraini \\ Departemen IImu Kelautan, Fakultas Perikanan dan IImu Kelautan, Universitas Diponegoro \\ Jl. Prof. Soedarto, SH Tembalang, Semarang, 50275 \\ ${ }^{*}$ Corresponding author, e-mail: muhammadjulihendra@gmail.com
}

\begin{abstract}
ABSTRAK : Rajungan (Portunus pelagicus) memiliki nilai ekonomi tinggi, berbanding lurus dengan penangkapan yang meningkat. Tingkat pemanfaatan yang tidak konservatif akan mempengaruhi ukuran dan kondisi rajungan di suatu populasi, serta stok rajungan di suatu perairan. Penelitian bertujuan untuk mengetahui kajian konservasi rajungan (Portunus pelagicus) berdasarkan morfometri dan sex ratio yang didaratkan oleh nelayan di Perairan Desa Gegunung Wetan, Kecamatan Rembang, Kabupaten Rembang. Metode yang digunakan dalam penelitian bersifat deskriptif. Pengamatan rajungan dilakukan pada salah satu pengepul di Desa. Rajungan di amati berdasarkan morfometri dan sex rasio selama 30 hari. Hasil Informasi dapat dijadikan pedoman dalam menentukan kebijakan mengenai pengelolaan perikanan rajungan yang berkelanjutan dan bersifat konservatif. Hasil dari penelitian diketahui bahwa kelimpahan rajungan jantan sebesar 46\% (1379 ekor) rajungan betina 56\% (1621 ekor) dari 3000 ekor sampel rajungan. Rasio perbandingan jantan dan betina 1:1,18. Berdasarkan distribusi ukuran lebar karapas rajungan di perairan Rembang adalah berkisar anatara 72-167 mm dan distribusi berat sebesar 40-303 gram. Distribusi tingkat kematangan gonad pada perairan Rembang adalah 608 ekor pada TKG 1; 658 ekor pada TKG 2; dan 355 pada TKG 3. Data menunjukan bahwa pola pertumbuhan rajungan yang ada di perairan Rembang adalah allometrik negatif baik rajungan jantan maupun rajungan betina
\end{abstract}

Kata kunci : Portunus pelagicus; Konservasi; Morfometri; Sex Rasio; Gegunung Wetan

\section{Morphometric Aspects and Sex Ratio of Blue Swimming Crab That Landed in Rembang Waters}

\begin{abstract}
Blue swimming crab (Portunus pelagicus) has a high economic value, directly proportional to the increased catch. The level of non-conservation utilization will affect the size and condition of the blue swimming crab in a population, as well as the blue swimming crab stock in a waters. This study is aimed to determine the blue swimming crab conservation study (Portunus pelagicus) based on morphometry and sex ratio brought by fishermen in the waters of Gegunung Wetan Village, Rembang District, Rembang Regency. The method used in this study is descriptive. Observation of blue swimming crab samples was carried out in one of the collectors in the village. Blue swimming crab was observed based on morphometry and sex ratio for 30 days. Informative results can be used as a guide in determining policies regarding sustainable and conservation management of blue swimming crab fisheries. The results of the study revealed that the abundance of male blue swimming crab was 46\% (1379 male blue swimming crab) and the abundance of the female blue swimming crab was 56\% (1621 female blue swimming crab) of 3000 blue swimming crab samples. The ratio of male and female is 1:1.18. Based on the size distribution of the width of the blue swimming crab carapace in the waters of Getanung Wetan it ranges from $72-167 \mathrm{~mm}$ and the distribution of weight is $40-303$ grams. $13.8 \%$ (413 blue swimming $\mathrm{crab}$ ) sized $\leq 10 \mathrm{~cm}$ and $86.2 \%$ (2587 blue swimming crab) sized $\geq 10 \mathrm{~cm}$. The distribution of gonad maturity level in the waters of Gegunung Wetan is 608 female blue swimming crab at TKG 1; 658 female blue swimming crab at TKG 2; and 355 female blue swimming crab at TKG 3 . There were 355 female blue swimming crab (22\%) of the total female blue swimming crab laying eggs. The data showed that the blue swimming crab growth pattern in Gegunung Wetan waters was negative allometric both male and female blue swimming crab.
\end{abstract}

Keywords : Portunus pelagicus; Morphometry; Sex Ratio; conservation; Gegunung Wetan 


\section{PENDAHULUAN}

Rajungan merupakan komoditas ekspor perikanan yang memiliki nilai ekonomis yang tinggi. Nilai ekspor rajungan-kepiting pada tahun 2015mencapai 310 juta USD, dan terus meningkat pada tahun 2016 adalah 322 juta USD. Bahkan pada tahun 2017 nilai ekspor kembali meningkat mencapai 411 juta USD (BPS, 2017). Salah satu lokasi penangkapan rajungan di Indonesia adalah di perairan Teluk Awur, Jepara. Berdasarkan data Statistik Perikanan Tangkap Indonesia (KKP, 2011) menunjukkan bahwa produksi perikanan pada periode tahun 2001-2011, volume produksi perikanan tangkap meningkat rata-rata sebesar 2,93\% per tahun, yaitu tahun 2001 sebanyak 4.276.720 ton menjadi 5.714.271 ton pada tahun 2011. Volume produksi perikanan tangkap di laut pada periode tersebut meningkat rata-rata sebesar 3,06\% per tahun, yaitu dari 3.966.480 ton pada tahun 2001 menjadi 5.345.729 ton pada tahun 2011.

Berdasarkan data Keputusan Menteri Kelautan dan Perikanan Republik Indonesia Nomor 70/Kepmen-Kp/2016, penangkapan rajungan di Rembang sudah melampaui batas ambang atau tidak normal dalam angka laju eksploitasinya bernilai 0,78/tahun. Berdasarkan angka laju eksploitasi menunjukan telah terjadi pemanfaatan yang berlebihan dan pada tahapan upaya penangkapan yang berlebih (over exploited).

Masyarakat Gegunung Wetan sebagian besar memiliki mata pencaharian utama sebagai nelayan rajungan. Mereka pada umumnya menggunakan bubu lipat untuk menangkap rajungan (Ubaidillah, 2014). Menurut nelayan, hasil tangkapan rajungan menurun dari tahun ke tahun. Selain itu ukuran rajungan juga menurun, yang menurut Kardi (2007) merupakan indikasi dari kegiatan overfishing yang dipicu oleh permintaan rajungan yang tinggi, dikhawatirkan dapat berpengaruh dengan struktur ukuran rajungan yang ada di alam (Hamid et al., 2015) dan tingkat permintaan rajungan juga akan berpengaruh pada status stok diperairan, terlebih jika dilakukan pada rajungan muda (Damora dan Nurdin, 2016).

Menindak lanjuti dari peraturan Menteri Kelautan dan Perikanan No.1/PERMEN-KP/2015 tentang pelarangan penangkapan rajungan dengan lebar $\leq 10 \mathrm{~cm}$ dan rajungan betina yang sedang bertelur. Namun fakta dilapangan masih terdapat rajungan yang berukuran dibawah $10 \mathrm{~cm}$ dan rajungan yang matang gonad (ovigerrous) tertangkap di perairan. Oleh karena itu perlu adanya informasi mengenai ukuran dan kondisi rajungan yang ada di Gegunung Wetan, Rembang sebagai acuan penangkapang yang bersifat konservatif. Tujuan penelitian adalah melakukan kajian morfometri dan sex rasio pada rajungan (Portunus pelagicus) yang tertangkap di Perairan Rembang

\section{MATERI DAN METODE}

Materi yang digunakan dalam penelitian ini adalah 3000 ekor rajungan dari perairan Gegunung Wetan, Rembang. Alat tangkap yang digunakan oleh nelayan adalah bubu lipat. Pengambilan data parameter lingkungan dilakukan dengan mengukur nilaisuhu, salinitas, dan kecerahan.Sampel diambil dari hasil tangkapan nelayan yang dikumpulkan kepada pengepul, dengan memilih rajungan yang masih dalam kondisi yang baik (bagian tubuhnya lengkap). Pengamatan rajungan dilakukan satu kali dalam sehari pada siang, selama 30 hari.

Data pengukuran rajungan yang diambil yaitu meliputi pengukuran berat tubuh rajungan dan lebar karapas (CW). Pengukuran berat tubuh dilakukan dengan menimbang rajungan dengan timbangan analitik, sedangkan pengukuran lebar karapas dilakukan dengan jangka sorong (Gambar 1). Selanjutnya dilakukan pengamatan jenis kelamin rajungan.

Rajungan diidentifikasi jenis kelaminnya dari warna karapas dan abdomennya. Rajungan jantan memiliki karapas yang berwarna biru cerah (Komar et al, 2003; Susanto, 2004). Sedangkan rajungan betina memiliki karapas berwarna coklat. Selain itu abdomen rajungan betina terlihat lebih membulat dibandingkan rajungan jantan yang memiliki abdomen lebih runcing (Sukumaran dan Neelakantan, 1997).

Sesuai dengan panduaan pengamatan Rajungan yang dirumuskan oleh APRI (2017), pengamatan tingkat kematangan gonad secara visual yang dilakukan pada rajungan betina terbagi penjadi 3 (tiga) Tingkat Kematangan. Rajungan betina yang tidak terdapat tanda telur ditandai dengan Tingkat Kematangan (1), rajungan yang sudah terdapat tanda telur namun belum keluar 


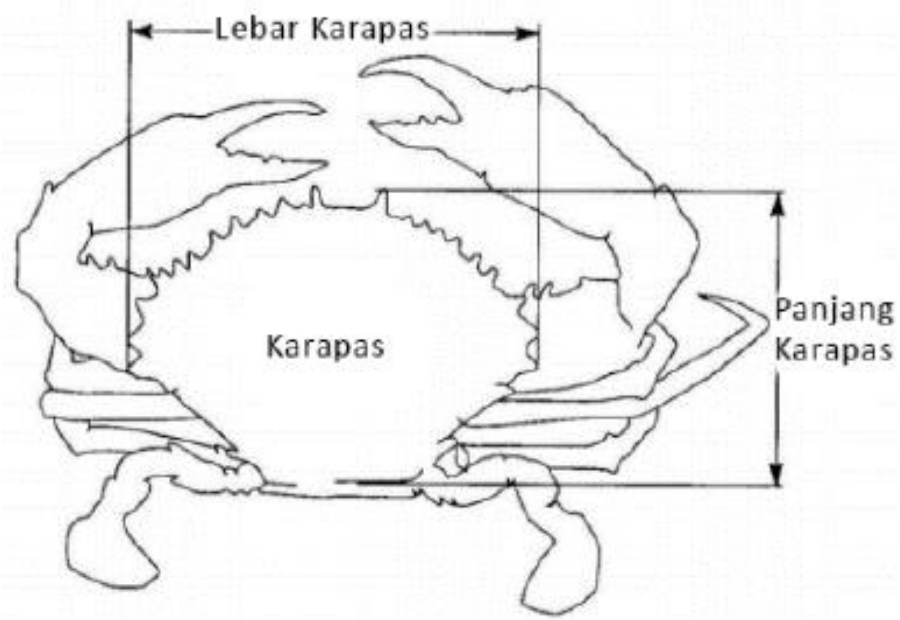

Gambar 1. Cara Mengukur Lebar Karapas Rajungan (Portunus pelagicus) Sumber : APRI, 2017

dari abdomen ditandai dengan Tingkat Kematangan (2). Sedangkan rajungan yang matang gonad (ovigerous) ditandai dengan Tingkat Kematangan (3).

Parameter lingkungan diamati secara insitu di lapangan, dengan mengambil data suhu, salinitas, kecerahan, kedalaman, Ph berturut-turut menggunakan termometer, refraktometer, sechi disc, tali, dan Ph meter. Data ini diambil sebagai data sekunder penelitian. Distribusi lebar karapas dan berat rajungan dianalisa dengan menggunakan Software Microsoft Excel, dengan menginput data lebar karapas dan berat rajungan dan kemudian disajikan didalam grafik distribusi. Nisbah kelamin dapat dihitung menurut Tahmid et al. (2017). Menurut Tuhuteru (2004), untuk mengetahui keseimbangan nisbah kelamin, perlu dilakukan Uji Chi-Square.

Kelimpahan rajungan jantan dan betina dalam suatu populasi atau perairan menurut Syahidah et al. (2005).Lebar karapas dan berat tubuh rajungan dianalisa dengan menggunakan regresi untuk mengetahui perbandingan antara lebar karapas dan berat tubuh rajungan (Kamrani et al., 2010). Nilai b digunakan untuk menduga laju pertumbuhan kedua parameter yang dianalisis. Hipotesis digunakan sebagai berikut : (1) Jika nilai $b=3$ maka disebut pola pertumbuhan isometrik (pola pertambahan lebar dan dan berat sama); (2) Jika nilai $b>3$ maka disebut pola pertumbuhan alometrik positif (pertambahan berat lebih cepat dari pada pertambahan lebar); (3) Jika nilai $b<3$ maka disebut pola pertumbuhan alometrik negatif (pertambahan lebar lebih cepat daripada pertambahan beratnya) (Kangas, 2000). Nilai b pada pola pertumbuahan dianalisis tingkat signifikanya menggunakan uji $t$ test menurut prosedur Siringoringo et al., 2017,

Analisis tingkat kematangan gonad berupa distribusi tingkat kematangan gonad rajungan betina menggunakan software Microsoft excel. Distribusi diicari dengan menghitung jumlah rajungan betina pada setiap tingkat kematangan gonad kemudikan disajikan kedalam grafik batang. Analisis konservasi penangkapan rajungan mengacu pada Peraturan Menteri Kelautan dan Perikanan No1/PERMEN-KP/2015 tentang pelarangan penangkapan rajungan yang berukuran $\leq 10 \mathrm{~cm}$ dan tidak sedang kondisi bertelur.

\section{HASIL DAN PEMBAHASAN}

Distribusi ukuran rajungan terbagi dalam dua kelompok, yaitu rajungan dengan ukuran $\geq 10$ $\mathrm{cm}$, dan rajungan dengan ukuran $\leq 10 \mathrm{~cm}$. Rajungan jantan yang berukuran $\leq 10 \mathrm{~cm}$ terdapat $15 \%$ (213 ekor) dan $85 \%$ (1166 ekor) dari total rajungan jantan adalah berukuran $\geq 10 \mathrm{~cm}$ sedangkan $12 \%$ (200 ekor ) dari rajungan betina berukuran $\leq 10 \mathrm{~cm}$ dan $88 \%$ (1421 ekor) berukuran $\geq 10 \mathrm{~cm}$. Berdasarkan keseluruhan pengamatan sampel rajungan terdapat 13,8\% (413 ekor) yang memiliki lebar karapas $\leq 10 \mathrm{~cm}$ dan $86,2 \%$ (2587 ekor) merupakan rajungan yang berukuran $\geq 10 \mathrm{~cm}$. Hasil penelitian menunjukkan $13,8 \%$ atau 413 ekor dari total tangkapan adalah rajungan yang dilarang ditangkap karena memiliki lebar karapas $\leq 10 \mathrm{~cm}$ tidak memenuhi standar yang sudah ditetapkan. 
Sebaran lebar karapas selama penelitian menunujukkan,lebar minimum dari total rajungan yang diamati adalah $72 \mathrm{~mm}$ sedangkan lebar maksimum adalah $167 \mathrm{~mm}$.Rajungan jantan dan betina paling sedikit pada kisaran 160-167 mm yaitu 1 ekor rajungan betina dan 2 ekor rajungan jantan, pada lebar kelas $104-111 \mathrm{~mm}$ terdapat jumlah terbanyak yaitu 1010 ekor dengan jumlah jantan sebanyak 365 ekor dan jumlah betina sebanyak 645 ekor (Gambar 2). Hasil ini lebih kecil jika dibandingkan dengan penelitian yang dilakukan oleh Setiyowati (2016) di perairan Telukawur lebar rajungan di dominasi rajungan yang berukuran 139,1 mm. Nilai ini juga lebih kecil jika dibandingkan dengan rajungan yang di perairan Kepulauan Aru, yang memiliki puncak jumlah pada lebar karapas $139-150 \mathrm{~mm}$. Puncak berdasarkan lebar karapas di Perairan Gegunung Wetan, Rembang lebih kecil jika dibandingkan dengan di Kabupaten Bintan, Kepulauan Riau, yang memiliki jumlah puncak pada lebar karapas $115 \mathrm{~mm}$ (Tahmid et al., 2017).

Sedangkan menurut sebaran beratnya, ukuran berat tubuh minimum 40 gram dan berat tubuh maksimal terdapat pada kisaran berat 282-303 gram. Kelas ukuran berat tubuh rajungan tertinggi 84-105 gram sebanyak 946 ekor terdapat pada kisaran kelas 84-105 gram yaitu 351 ekor rajungan jantan dan 595 rajungan betina. Sedangkan jumlah paling sedikit pada kisaran bobot 260-281 gram yaitu 2 ekor rajungan jantan (Gambar 3). Hasil puncak frekuensi berat yang didapat lebih kecil jika dibandingkan dengan rajungan yang tertangkap di kabupaten Rembang dengan puncak frekuensi berat pada 161,5-187,9 gr (Arios et al., 2013).

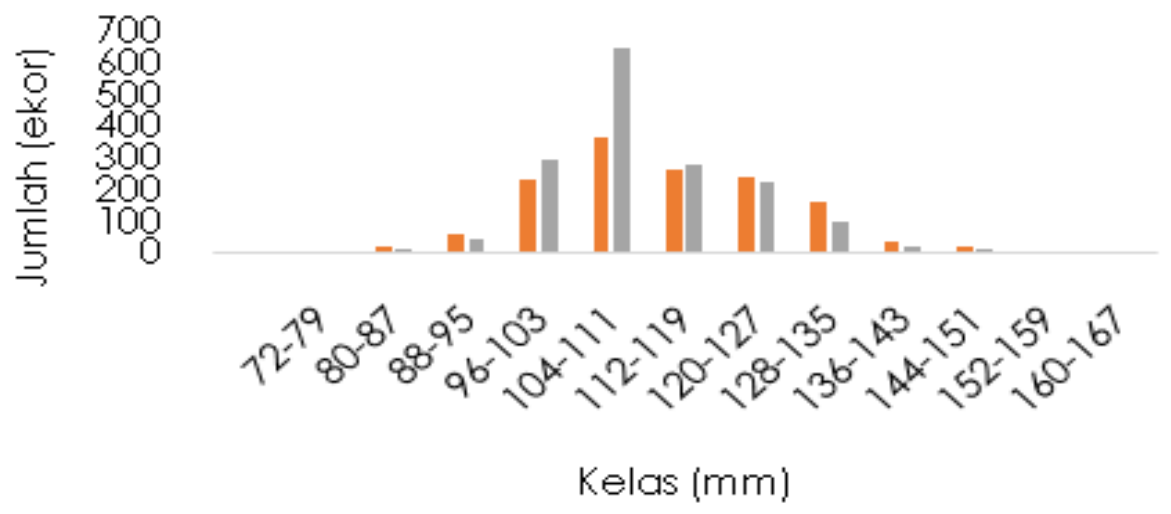

- Jumlah Jantan (ekor) = Jumlah Betina (ekor)

Gambar 2. Sebaran Lebar Karapas (mm) Rajungan (Portunus pelagicus) di Perairan Gegunung Wetan.

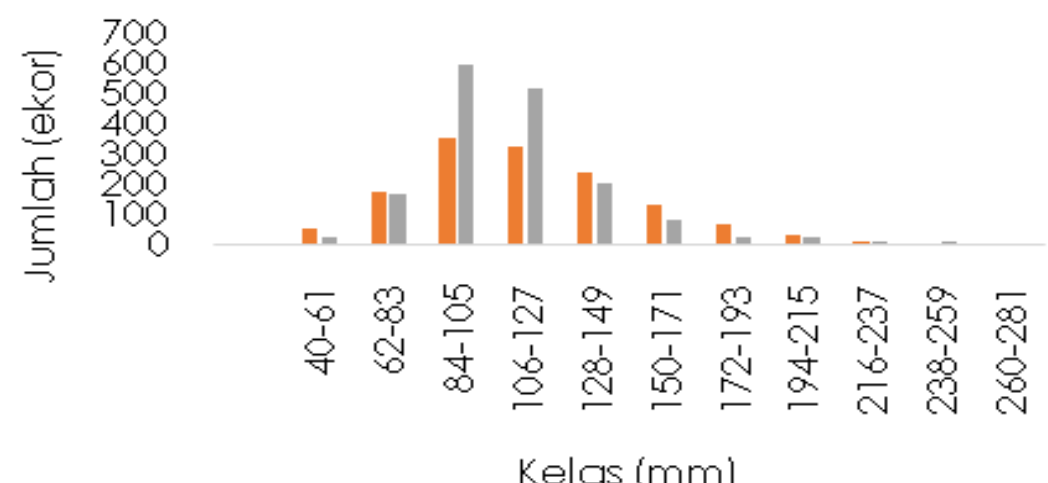

- Jumlah Jantan (ekor) = Jumlah Betina (ekor)

Gambar 3. Sebaran Berat Tubuh (gram) Rajungan (Portunus pelagicus) di Perairan Gegunung Wetan 
Perbedaan ukuran dapat dipengaruhi oleh beberapa faktor. Dalam penelitian Adam dan Sondita (2006), menyatakan bahwa semakin jauh dari pantai, rata-rata lebar karapas rajungan meningkat dan konstan pada jarak tertentu. Sehingga diketahui bahwa wilayah tangkapan menjadi salah satu faktor yang mempengaruhi ukuran lebar karapas, selain faktor lingkungan, dan tekanan penangkapan yang berbeda di setiap lokasi penelitian (Ernawati., 2015). Tekanan penangkapan yang tinggi menyebabkan banyak rajungan tertangkap termasuk rajungan dengan ukuran yang masih kecil.

Rasio jantan dan betina selama 30 hari penelitian menunjukkan pola fluktuatif yang artinya penangkapan rajungan di perairan Gegunung Wetan bervariasi antara jantan dan betina. Rasio perbandingan rajungan jantan dan betina berturut turut pada hasil penelitian adalah 1: 1,18. Berdasarkan Uji chi square nilai $X_{2}$ hitung sebesar 19,54 sedangkan nilai $X$ tabel 74,875 . Menurut hipotesis pada Uji chi square apabila $X_{2}$ hitung $<X$ tabel maka populasi rajungan masih dikatakan seimbang. Hasil penelitian sejalan dengan Ningrum et al., (2015) menyatakan bahwa rasio kelamin antara rajungan jantan dan betina di perairan Betahwalang Kabupaten Demak sebesar 1:1,1 dan di Sulawesi tenggara yang jumlah jantan dan betinanya seimbang (Kembaren dan Surahman, 2018). Hasil penelitian berbeda dari Kota Baru dan Lampung timur, jumlah rajungan jantan lebih dominan (Damora dan Nurdin, 2016; Tirtadanu et al., 2017).

Jumlah keseluruhan rajungan yang diamati selama penelitian yaitu 3000 ekor dengan rincian 100 ekor/hari. Hasil pengamatan menunjukan jumlah rajungan jantan sebanyak 1379 ekor (46\%) dan jumlah rajungan betina sebanyak 1621 ekor (54\%) (Gambar 4).Perbedaan jumlah jantan dan betina dipengaruhi oleh beberapa faktor seperti musim, lokasi tangkapan, migrasi, ketersediaan makanan (La Sara et al., 2002). Pada musim memijah, yakni padabulan Desember, Maret, Juli, dan September, rajungan betina akan bermigrasi ke perairan yang memiliki salinitas yang lebih tinggi. Sehingga pada musim memijah daerah laut lepas didominasi oleh rajungan betina (Juwana dan Romimoharto, 2005).

Analisis hubungan lebar karapas dan berat rajungan di perairan Gegunung Wetan menunjukkan hasil nilai $b<3$ dan hasil uji $t$ square didapatkan Keputusan $=t_{\text {hitung }}>t_{\text {tabel }}\left(\right.$ Tolak $\left.\mathrm{H}_{0}\right)$ maka pola pertumbuhan bersifat allometrik, dan karena nilai $b<3$ maka pola pertumbuhannya allometrik negatif baik rajungan betina maupun rajungan jantan (Gambar 5 dan Gambar 6). Hasil ini menggambarkan bahwa pertumbuhan lebar karapas rajungan lebih dominan dibandingkan dengan pertumbuhan bobot tubuhnya. Hasil penelitian ini sama dengan pola pertumbuhan rajungan yang diperoleh Aslan et al. (2003), di perairan Purirano, Kendari, Sulawesi Tenggara yaitu allometrik negatif baik pada jantan maupun betina. Hasil sejalan dengan penelitian dari Atar et al., (2003) yang mendapatkan nilai $b<3$ (allometrik negatif) pada Blue crab (Callinectus sapidus) di perairan Lagoon Lake Turkey dan di Perairan Lakara, Sulawesi Tenggara yaitu allometrik negatif baik pada fase bulan purnama maupun bulan baru. Namun hasil tersebut berbeda dengan hasil penelitian di perairan Pati dan Betahwalang Demak yang diperoleh pertumbuhan rajungan adalah allometrik positif ( $b>3$ ) (Ernawati et al., 2015 dan Ningrum et al., 2015).

Perbedaan pola pertumbuhan pada rajungan jantan dan betina menurut Hartnoll et al, (1982) dapat disebabkan faktor luar yakni adanya perbedaan iklim mikro yang optimum seiring perubahan musim, dan jumlah makanan, serta faktor dalam yakni jenis kelamin, tingkat kedewasaan, dan anggota tubuh yang hilang. Menurut Kembaren dan Surahman (2018) bahwa ketersediaan pakan alami yang mencukupi di habitatnya akan menyebabkan pertumbuhan rajungan relatif cepat, karena persediaan energi untuk melakukan proses metabolisme tercukupi. Sedangkan tekanan penangkapan yang tinggi menyebabkan terganggunya proses pertumbuhan rajungan. Menurut Dody (2010), menyatakan bahwa perbedaan laju pertumbuhan dengan ukuran cangkang yang berbeda menunjukkan bahwa kecepatan pertumbuhan dari setiap individu adalah tidak sama, yang disebabkan oleh kemampuan dalam memanfaatkan energi serta meminimalisir pengaruh faktor fisiologi dan faktor-faktor lain yang berbeda. Clemente (2011), menyatakan bahwa pola pertumbuhan ditentukan oleh strategi hidup dan kondisi lingkungan. Menurut Kurniasih (2008) dalam Rahmansyah (2012) menambahkan bahwa Crustacea yang mendapat kandungan gizi yang yang cukup akan lebih cepat mengalami pergantian kulit karena energi yang tersimpan dalam makanan dimetabolisme dan digunakan untuk pemeliharaan dan pertumbuhan. 


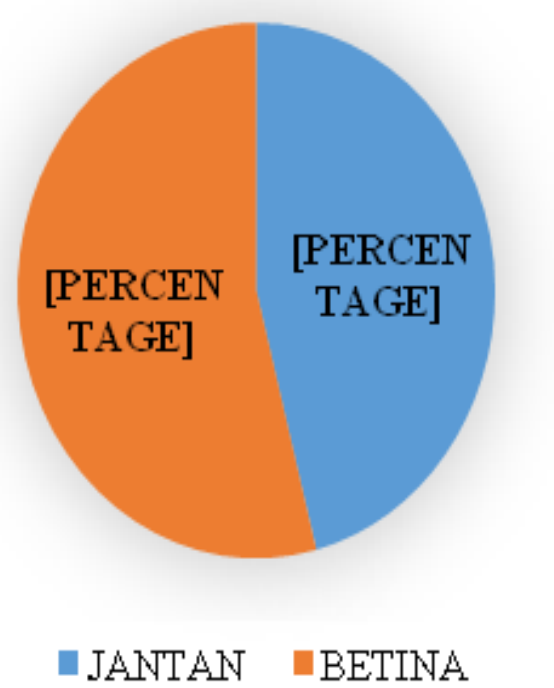

Gambar 4. Presentase Kelimpahan Rajungan (Portunus pelagicus) Selama Penelitian di Perairan Gegunung Wetan

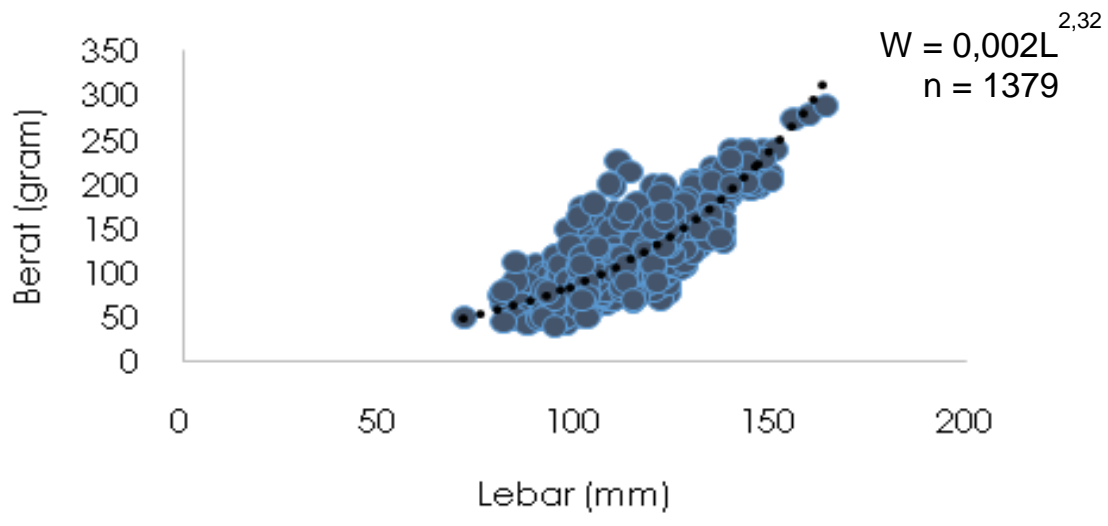

Gambar 5. Hubungan Lebar Karapas - Berat Rajungan Jantan di Perairan Gegunung Wetan

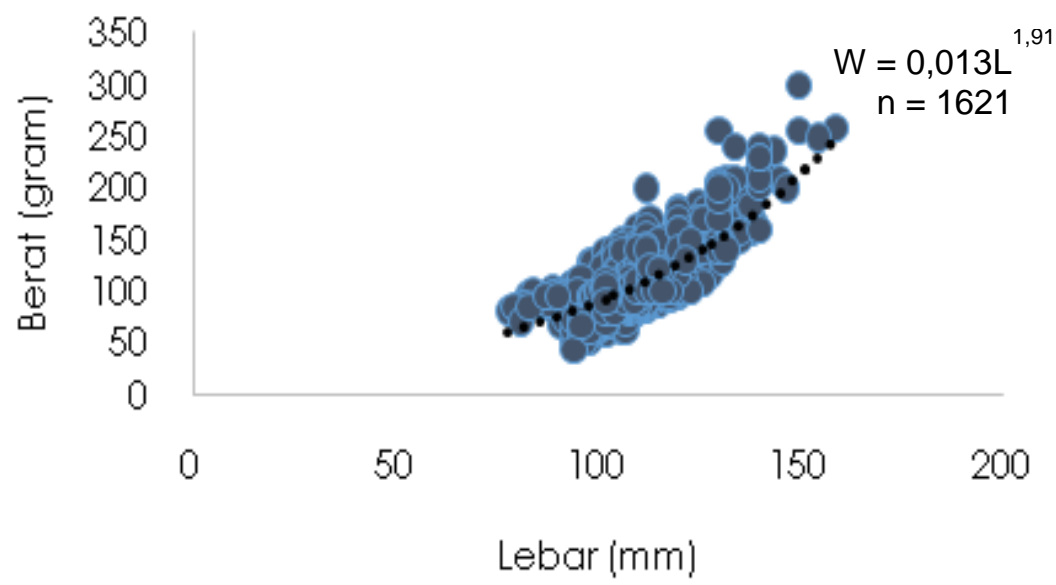

Gambar 6. Hubungan Lebar Karapas - Berat Rajungan Jantan di Perairan Gegunung Wetan

Sebaran Tingkat Kematangan Gonad berdasarkan hasil penelitian didapatkan pada TKG 1 sebanyak 608 ekor, TKG 2 sebanyak 658 ekor dan TKG 3 sebanyak 355 ekor. Berdasarkan ukuran $\leq 10 \mathrm{~cm}$ rajungan batina yang termasuk kedalam TKG 3 sebanyak 31 ekor $(9,5 \%)$; TKG 2 
sebanyak 89 ekor (5,8\%); dan TKG 1 sebanyak 80 ekor (12,6\%), hasil total keseluruhan rajungan betina yang tertangkap dan masih berukuran $\leq 10 \mathrm{~cm}$ adalah 200 ekor $(12,3 \%)$. Rajungan betina yang termasuk dalam fase tingkat kematangan gonad 3 atau rajungan yang sedang membawa telur (ovigerrous) sebanyak 22\% (355 ekor) dari total rajungan betina yang artinya jumlah yang banyak untuk rajungan betina tersebut dilarang ditangkap (Tabel 1).

Hal ini berbeda dengan di perairan Teluk Banten, pengamatan tingkat kematangan gonad rajungan betina lebih di dominasi rajungan yang mengalami tingkat kematangan gonad 3 (Fauzi et al., 2018), sedangkan di perairan Kepulauan Aru, dan perairan tenggara Australia, yang di dominasi oleh yang rajungan betina yang sudah matang gonad (Kembaren dan Surahman, 2018). Terdapat beberapa faktor yang mempengaruhi dominasi TKG rajungan pada suatu perairan. Ernawati (2015) menyebutkan bahwa puncak pemijahan di perairan daerah Pati ada pada bulan Oktober, sedangkan puncak musim pemijahan di perairan timur Lampung adalah pada bulan AprilJuni dan September-Oktober/November (Damora dan Nurdin, 2016),. Hal ini dapat menjelaskan perbedaan tingkat kematangan gonad pada masing-masing lokasi penelitian, salah satunya disebabkan oleh perbedaan musim pemijahan. Selain itu temperatur perairan juga mempengaruhi tingkat kematangan gonad rajungan, karena pada suhu hangat perkembangan ovarium lebih cepat (Svane \& Hooper, 2004).

Hasil pengukuran suhu pada lokasi penangkapan berkisar pada $23-27^{\circ} \mathrm{C}$, hasil pengukuran masih optimal untuk siklus hidup dan tingkah laku rajungan di perairan untuk berkembang biak. Hasil lebih rendah jika dibandingkan dengan perairan Betahwalang yang memiliki kisaran suhu antara $28-35^{\circ} \mathrm{C}$, dan Pulau Salemo yang dengan kisaran suhu anatara $29-32^{\circ} \mathrm{C}$ (Prasetyo, 2014 dan Nurdin et al., 2016). Dari hasil ini diketahui bahwa suhu perairan Gegunung Wetan, Rembang masih tergolong kedalam kisaran suhu yang mendukung kehidupan rajungan, yakni antara 17-37 ${ }^{\circ} \mathrm{C}$ (Perkins, 1974) (Tabel 2) .

Salinitas pada lokasi penangkapan berkisar antara $32 \%$ - $33 \%$. Rentang salinitas tersebut masih sangat baik bagi kelangsungan hidup dan pertumbuhan rajungan. Menurut Juwana (1997), rajungan yang masih kecil (zoea-megalopa) cocok pada perairan yang memiliki salinitas berkisar antara $28-32 \%$. Sedangkan untuk rajungan yang mengalami pematangan telur berkisar 33-34\%. Pada masa dewasa rajungan membutuhkan salinitas yang lebih tinggi sehingga Putra et al., (2019), menyatakan rajungan dapat hidup pada kisaran salinitas mencapai $40 \%$. Hasil ini lebih tinggi jika dibandingkan perairan Lombok Timur yang memiliki salinitas pada kisaran 31-32 \%o (Santoso, 2016).

Tabel 1. Sebaran Tingkat Kematangan Gonad berdasarkan Ukuran Lebar Karapas

\begin{tabular}{clccc}
\hline \multirow{2}{*}{ No } & \multicolumn{2}{c}{ Lebar Kelas $(\mathrm{cm})$} & \multicolumn{3}{c}{ Tingkat Kematangan Gonad (Ekor) } \\
\cline { 3 - 5 } & & TKG I & TKG II & TKG III \\
\hline 1 & $7,8-8,5$ & 6 & 1 & 3 \\
2 & $8,6-9,3$ & 3 & 13 & 8 \\
3 & $9,4-10,1$ & 77 & 63 & 40 \\
4 & $10,2-10,9$ & 225 & 184 & 125 \\
5 & $11-11,7$ & 127 & 175 & 94 \\
6 & $11,8-12,5$ & 85 & 138 & 42 \\
7 & $12,6-13,3$ & 46 & 64 & 21 \\
8 & $13,4-14,1$ & 37 & 16 & 16 \\
9 & $14,2-14,9$ & 1 & 1 & 2 \\
10 & $15-15,7$ & 1 & 2 & 0 \\
11 & $15,8-16,5$ & 0 & 1 & 0 \\
12 & $16,6-17,3$ & 0 & 0 & 355 \\
\hline \multicolumn{7}{c}{} & 608 & 658 & \\
\hline
\end{tabular}


Tabel 2. Pengukuran Parameter Lingkungan

\begin{tabular}{ccc}
\hline Parameter & Hasil Pengukuran & Kondisi Optimal \\
\hline Suhu $\left({ }^{\circ} \mathrm{C}\right)$ & $27-30$ & $24-30$ (Sumber: Juwana, 1997) \\
Salinitas $(\% \circ)$ & $32-34$ & $30-34$ (Sumber: Juwana, 1997) \\
$\mathrm{pH}$ & $7-8$ & $7-8,5$ (Sumber: Juwana, 1997) \\
Kedalaman $(\mathrm{m})$ & $>5$ & $7-25$ (Sumber: Nontji, 1993) \\
Kecerahan $(\mathrm{m})$ & $2,75-3,25$ & $2,8-3,4$ (Sumber: Yusuf, 2000) \\
\hline
\end{tabular}

Kecerahan pada lokasi penangkapan rajungan berkisar pada 2,75 m - 2,9 m. Hasil ini lebih tinggi jika dibandingkan dengan perairan Betahwalang yang kecerahannya berkisar anatara 0,180,13 m dan Kabupaten Bintan dengan kisaran 0,1-0,21 m (Pamuji, 2015). Perbebdaan kecerahan dapat dipengaruhi oleh bahan-bahan tersuspensi dan koloid yang terdapat pada perairan seperti lumpur, plankton, mikroorganisme, dan bahan organik (Mason, 1981).

Hasil penelitian pada kedalaman menunjukkan lokasi penangkapan rajungan mmiliki kedalaman $\pm 7-25$ meter. Rajungan merupakan hewan ektotermik atau pelagis, rajungan sangat menyukai kedalaman yang berkisar antara 10-20 meter, artinya siklus hidup rajungan muda lebih senang dengan laut yang dalam karena rajungan muda memiliki kemampuan berenang renang untuk mencari cadangan makanan, dan untuk proses metabolismenya rajungan lebih suka di tempat yang dalam dan bersuhu hangat.

\section{KESIMPULAN}

Distribusi ukuran lebar karapas terdapat $86,2 \%$ (2587 ekor) rajungan berukuran $\geq 10 \mathrm{~cm}$, dan $13,8 \%$ (413 ekor) rajungan berukuran $\leq 10 \mathrm{~cm}$. kelimpahan jantan $46 \%$ (1379 ekor) dan betina $54 \%$ (1621 ekor) dengan rasio perbandingan $1: 1,18$. Distribusi kematangan gonad dari 1621 ekor total rajungan betina didapatkan pada TKG 1 sebanyak 608 ekor, TKG 2 sebanyak 658 ekor dan pada TKG 3 sebanyak 355 ekor, hasil menunjukan sebanyak 355 ekor rajungan betina yang sedang membawa telur (ovigerrous). Pola pertumbuhan rajungan yang ada di perairan Gegunung bersifat allometrik negatif. Kesimpulan yang dapat diambil dari data pengkajian hasil penelitian diatasadalah Nelayan Gegunung Wetan melakukan penangkapan yang belum konservatif dan belum melaksanakan aturan penangkapan layak tangkap yang sudah ditetapkan.

\section{DAFTAR PUSTAKA}

Asosiasi Pengelolaan Rajungan Indonesia Kab. Pemalang. 2017. Pemalang Bertekad Pelihara Laut Pertahankan Kelestarian Rajungan. (Diakses 20 April 2019 pukul 21.00 WIB).

Badan Pusat Statistik (BPS). 2017. Statistik Perdagangan Luar Negeri ekspor 2017 Jilid I. Badan Pusat Statistik. Jakarta.

Damora, A. \& Nurdin, E., 2016. Beberapa aspek biologi rajungan (Portunus pelagicus) di perairan Labuhan Maringgai, Lampung Timur. Bawal Widya Riset Perikanan Tangkap, 8(1):13-20.

Ernawati, T., Boer, M. \& Yonvitner, Y. 2015. Biologi Populasi Rajungan (Portunus pelagicus) di Perairan Sekitar Wilayah Pati, Jawa Tengah. Widya Riset Perikanan Tangkap, 6(1):31-40.

Fauzi, M.J., Gaffar, A., Erdyanto, B., Dhewang, I.B., Arafat, M.A., Akmalia, D.A. \& Triyono, H., 2018. Pendugaan Growth Overfishing Rajungan (Portunnus pelagicus) di Teluk Banten. Jurnal Perikanan dan Kelautan, 8(1):96-103.

Hamid, A. \& Wardiatno, Y., 2015. Population dynamics of the blue swimming crab (Portunus pelagicus Linnaeus, 1758) in Lasongko Bay, Central Buton, Indonesia. Aquaculture, Aquarium, Conservation \& Legislation, 8(5):729-739.

Juwana, S \& K. Romimohtarto. 2005. Biologi Laut IImu Pengetahuan tentang Biota Laut. Djambatan. Jakarta. 76 hal. 
Juwana, S. 1997. Tinjauan tentang Perkembangan Penelitian Budidaya Rajungan (Portunus pelagicus,Linn). Oseana, 22(4):1-12.

Kamrani, E., Sabili, A.N. \& Yahyavi, M., 2010. Stock assessment and reproductive biology of the blue swimming crab, Portunus pelagicus in Bandar Abbas coastal waters, northern Persian Gulf. Journal of the Persian Gulf, 1(2):11-22.

Kangas, M.I. 2000. Synopsis of the biology andexploitation of the blue swimmer crab Portunuspelagicus Linnaeus in WesternAustralia. FisheriesResearch Report No. 121. Fisheries WesternAustralia. Perth. 29 pp.

Kembaren, D.D. \& Surahman, A., 2018. Struktur Ukuran Dan Biologi Populasi Rajungan (Portunus Pelagicus Linnaeus, 1758) Di Perairan Kepulauan Aru. Jurnal Penelitian Perikanan Indonesia, 24(1):51-60.

Kementerian Kelautan dan Perikanan [KKP]. 2011. Statistik Perikanan Tangkap Indonesia, 2010. Direktoral Jendaral Perikanan Tangkap. Jakarta. Vol 11, No 1. Jakarta. 143 pp.

Kementerian Kelautan dan Perikanan. 2015. Peraturan Menteri Kelautan dan Perikanan Nomor 1 Tahun 2015 tentang Penangkapan Lobster (Panulirus spp.), Kepiting (Scylla spp.), dan Rajungan (Portunus pelagicus spp.). Jakarta (ID): Kementerian Kelautan dan Perikanan. 5 hlm.

Kumar, M.S., Xiao, Y., Venema, S. \& Hooper, G., 2003. Reproductive cycle of the blue swimmer crab, Portunus pelagicus, off southern Australia. Journal of the Marine Biological Association of the United Kingdom, 83(5):983-994.

La Sara, Ingles, J.A., Baldevarona, R.B., Aguilar, R.O., Laureta, L.V. \& Watanabe, S. 2002. Reproductive Biology of Mud Crab Scylla serrata in Lawele Bay, Southeast Sulawesi, Indonesia. Crustacean Fisheries, 88-95.

Mason, C. F. 1981. Biology of Freshwater Pollution. Longman. NewYork. 250p.

Ningrum, V.P., Ghofar, A. \& Ain C. 2015. Beberapa Aspek Biologi Perikanan Rajungan (Portunus Pelagicus) di Perairan Betahwalang dan Sekitarnya. Jurnal Saintek Perikanan, 11(1):62-71.

Nurdin, M.S., Ali, S.A. and Satari, D.Y., Distribusi Ukuran dan Pola Pertumbuhan Rajungan (Portunus pelagicus) di Pulau Salemo Kabupaten Pangkajene Kepulauan. Simposium Nasional Kelutan dan Perikanan III Univeristas Hasanudin, Makassar.

Pamuji, A., Muskananfola, M.R. \& A'in, C., 2015.. Pengaruh Sedimentasi terhadap Kelimpahan Makrozoobenthos di Muara Sungai Betahwalang Kabupaten Demak. Jurnal Saintek Perikanan, 10(2):129-135.

Perkins, F.J. 1974. The Biology of Estuarine and Coastal Waters. Academic Press Inc. (London) Ltd. New York

Prasetyo, G.D. 2014. Analisis Daeah Penangkapan Rajungan (Portunus pelagicus) berdasarkan perbedaan kedalaman perairan dengan Jaring Arad ( Mini Trawl) di Perairan Demak. Jurnal Manajemen dan Teknologi Sumberdaya Perikanan, 3(3):257-256.

Putra, E.M., Pramesti, R. \& Santosa, G.W.,. 2019. Morfometri Portunus pelagicus Linnaeus, 1758 (Malacostraca: Portunidae) Pada Fase Bulan Yang Berbeda Di Perairan Betahwalang, Demak Journal of Marine Research, 8(2):204-210.

Santoso, D. \& Raksun, A., 2016. Karakteristik Bioekologi Rajungan (Portunus Pelagicus) Di Perairan Dusun Ujung Lombok Timur. Jurnal Biologi Tropis, 16(2):94-105. DOI: 10.29303/jbt. v16i2.312

Sukumaran, K.K. \& Neelakantan B.. 1997. Sex rasio, fecundity and reproductive potential in two marine portunid crabs, Portunus (Portunus) sanguinolentus (Herbst) and Portunus (Portunus) pelagicus (Linnaeus) along the Karnataka Coast. Indian Journal of Marine Sciences 26:43-48

Susanto, B. M. Marzuki, dan I Setyadi, 2004. Pengamatan Aspek Biologi rajungan (Portunus pelagicus) dalam menunjang teknik pembenihannya warta penelitian perikanan Indonesia. 10 (1): 6-11 hal.

Syahidah D, Susanto, B. \& Setiadi, I., 2005. Percobaan Pemeliharaan Megalopa Rajungan (Portunus pelagicus) sampai menjadi Rajungan Muda (crablet-1) dengan Kisaran Salinitas Berbeda. Balai Besar Riset Perikanan Budidaya Laut Gondol, Bali. Prosiding Seminar Riptek Kelautan Nasional, 31-33 hal. 
Tahmid, M., Fahrudin, A. and Wardiatno, Y., 2017. Kajian Struktur Ukuran Dan Parameter Populasi Kepiting Bakau (Scylla serrata) di Ekosistem Mangrove Teluk Bintan, Kepulauan Riau. Jurnal Biologi Tropis, 15(2):93-106. DOI: 10.29303/jbt.v15i2.192

Tirtadanu \& Suman, A. 2017. Aspek Biologi, Dinamika Populasi Dan Tingkat Pemanfaatan Rajungan (Portunus Pelagicus Linnaeus, 1758) di Perairan Kotabaru, Kalimantan Selatan. Jurnal Penelitian Perikanan Indonesia, 23(3):205-214.

Ubaidillah, F. 2014. Perbedaaan Lama Penarikan dan Hasil Tangkapan pada Pengoperasian Bubu Rajungan (Portunus sp.) dengan Rancang Bangun Alat Penarik Tali Utama di Desa Betahwalang Kabupaten Demak. Journal of Fisheries Resources Utilization Management and Technology, 3(2):1-8. 